\title{
PREPARATION OF BICYCLIC LACTONES USING LEWIS ACIDS CATALYZED ENE-REACTION
}

\section{MAKAMA, B. Y.}

Department of Petroleum Chemistry, American University of Nigeria Lamido Zubairu Way, P.M.B. 2250 Yola, Adamawa State, Nigeria. bello.makama@aun.edu.ng

\section{INTRODUCTION}

The synthesis of the cis-fused bicyclic lactones relies extensively on the Lewis acid catalysed carbonyl-ene reaction which has been widely used to access carbocycles. In 1943 Alder discovered the ene-reaction and classified it in his Nobel Lecture as an "indirect substitution addition" or "ene synthesis" in 1950. The synthesis of the bicyclic lactone intermediate relies on the intramolecular ene reaction, a conversion that has been widely used as a tool to access polycycles. The conversion involves the reaction between an alkene having an allylic hydrogen (an"ene") and a compound containing an electron deficient double bond (an "enophile") to form a $\sigma$-bond with migration of the ene double bond and a 1,5-hydrogen shift (Scheme 1) (Snider, 1991).<smiles>[Y][Y]([H])([H])CC=C</smiles>

\section{Scheme 1. ALDER ENE REACTION}

As part of a programme aimed at the rapid and efficient synthesis of complex iridoid natural products, this paper reports efficient and novel process of synthesizing the precursor (4) via ene reaction (Scheme 2).

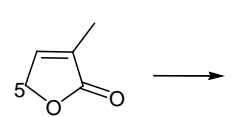

(1)

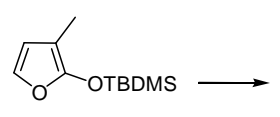

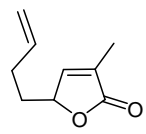

(3)<smiles>C=C1C(=O)OC2CCC(C)[C@H]12</smiles>

(4)

\section{Scheme 2. SYNTHETIC APPROACH TO BICYCLIC LACTONE (4)}

Reagents were obtained from Aldrich and Lancaster chemical suppliers. Dichloromethane was refluxed over and distilled from $\mathrm{CaH}_{2}$ prior to use. Diethyl ether was obtained dry from Aldrich. THF was dried by distillation from the sodium benzophenone ketyl radical under nitrogen. Light petroleum is the fraction of petroleum ether that boils in the range $30-40{ }^{\circ} \mathrm{C}$, and it was fractionally distilled through a $36 \mathrm{~cm}$ Vigreux column before use (Amarego \& Perrin, 1998).

Organic solutions were concentrated under reduced pressure on a Büchi rotary evaporator using a water bath. Thin-layer chromatography (TLC) was performed on Merck aluminium-backed plates coated with $0.2 \mathrm{~mm}$ silica gel $60-\mathrm{F}$ plates. Visualization of the developed chromatogram was performed by UV fluorescence quenching at $254 \mathrm{~nm}$, or by staining with a $\mathrm{KMnO}_{4}$ solution. ${ }^{1} \mathrm{H}$ and ${ }^{13} \mathrm{C}$ NMR spectra were recorded on a Bruker DPX250 (250 MHz for protons) and a Brüker AMX400 (400 MHz for protons). Data for ${ }^{1} \mathrm{H}$ NMR were reported as follows: chemical shift ( $\delta-p p m)$, multiplicity (s $=$ singlet, $\mathrm{d}=$ doublet, $\mathrm{t}=$ triplet, $\mathrm{q}=$ quartet, $\mathrm{m}=$ multiplet), integration, coupling constant in $(\mathrm{Hz})$. Data for ${ }^{13} \mathrm{C}$ NMR spectra were reported in terms of chemical shift (ppm) down field from TMS. IR spectra were recorded on a Perkin Elmer Paragon 1000 and a Perkin Elmer 881 spectrometer as a thin film between sodium chloride plates. Absorptions were measured $\left(\mathrm{cm}^{-1}\right)$. Mass spectrometric data were recorded on VG Autospec, under conditions of chemical ionisation (C.I) using ammonia as the ionising source. Peaks were quoted in the form $(\mathrm{m} / \mathrm{z}$ ) (relative intensity). Melting points were determined using a Reichert Kofler heated-stage microscope and were uncorrected.

\section{3-methyl 2-(tert-butyldimethylsiloxy)furan (2)}

To a stirred solution of 3-methyl-2-(5H)-furanone (1) $(1.00 \mathrm{~g}, 10.2$ $\mathrm{mmol}, 1.00$ equiv), triethylamine ( $1.36 \mathrm{~g}, 13.22 \mathrm{mmol}, 1.29$ equiv.), and dry ether $(7.5 \mathrm{~mL})$ under an atmosphere of nitrogen at $0{ }^{\circ} \mathrm{C}$ was added via syringe, tert-butyldimethylsilyl triflate $(3.23 \mathrm{~g}, 13.0 \mathrm{mmol}$, 1.27 equiv). After 3 hours water $(10 \mathrm{~mL})$ was added, the organic layer was separated, the residue was extracted with diethyl ether (3 $x 7.5 \mathrm{~mL}$ ). The ether layer was washed with cold aqueous saturated sodium hydrogen carbonate $(2 \times 5 \mathrm{~mL})$. The solvents were removed in vacuo and the residue was purified by flash column chromatography on silica, eluting with hexane : ether (5:1)

\section{5-(But-3-enyl)-3-methylfuran-2(5H)-one (3) \\ Method A}

To a stirred suspension of silver trifluoroacetate $(395 \mathrm{mg}, 1.8 \mathrm{mmol}$, 1.13 equiv) in dry dichloromethane $(10 \mathrm{~mL})$ under argon at $-78{ }^{\circ} \mathrm{C}$ was added 2-tert-butyldimethylsiloxy)-methylfuran (2) (350 mg, 1.6 $\mathrm{mmol}, 1.00$ equiv) followed by the dropwise addition of 4-boromobut-1-ene (220 mg, $16 \mathrm{mmol}, 1.00$ equiv) neat over a period of 5 minutes. The temperature was increased to $10{ }^{\circ} \mathrm{C}$ over $4 \mathrm{~h}$. The mixture was filtered through Celite ${ }^{\circledR}$, washing with ether $(4 \times 4 \mathrm{~mL})$. The solvent was removed carefully in vacuo and the crude material was purified by flash column chromatography on silica, eluting with hexane : ether (4:1).

\section{Method B}

To a stirred suspension of silver trifluoroacetate $(3.50 \mathrm{~g}, 15.8 \mathrm{mmol}$, 1.32 equiv. $)$ in dry dichloromethane $(32 \mathrm{~mL})$ under argon at $-78{ }^{\circ} \mathrm{C}$ was added 2-(tert-butyldimethylsiloxy)-methylfuran (2) (2.54 g, 12 $\mathrm{mmol}, 1.00$ equiv.) followed by the dropwise addition of 4 -iodobut1ene (5) $(2.85 \mathrm{~g}, 15.70 \mathrm{mmol}, 1.3$ equiv.) neat over a period of 10 minutes. The temperature was increased to $10^{\circ} \mathrm{C}$ over 4 hours. The mixture was filtered through $\mathrm{Celite}^{\circledR}$, washing with ether $(4 \times 32 \mathrm{~mL})$. The solvent was removed carefully in vacuo and the crude material was purified by flash column chromatography on silica, eluting with hexane: ether (4:1).

4-methyl-3methylene-hexahydrocyclopenta[b]furan-2-one (4) To a stirred a solution of 5-(But-3-enyl)-3-methylfuran-2(5H)-one (3) (200 mg, $1.31 \mathrm{mmol}, 1$ equiv) in dry dichloromethane $(7 \mathrm{~mL})$ under argon $-78{ }^{\circ} \mathrm{C}$ was added $\mathrm{BF}_{3}(115 \mathrm{mg}, 1.7 \mathrm{mmol}, 1.3$ equiv) and reaction was stirred for 24 hours by which time TLC analysis revealed the formation of a new product. Water $(10 \mathrm{~mL})$ was added and the organic layer separated, the residue was extracted with DCM $(4 \times 10 \mathrm{~mL})$. The DCM layer was washed with cold aqueous 
saturated sodium hydrogen carbonate $(2 \times 4 \mathrm{~mL})$. The solvents were removed in vacuo and the residue was purified by flash column chromatography on silica, eluting with hexane : ethyl acetate $(1: 1)$

\section{3-methyl 2-(tert-butyldimethylsiloxy)furan (2)}

The title compound was isolated as a colourless oil $(1.66 \mathrm{~g}, 77 \%)$; Umax (thin film/cm-1), 2999, 2956, 2887, 2865, 1656, 1261, 956, 851; $\delta_{\mathrm{H}}\left(250 \mathrm{MHz}, \mathrm{CDCl}_{3}\right) 6.69(1 \mathrm{H}, \mathrm{d}, \mathrm{J} 2.2 \mathrm{~Hz}, \mathrm{CHO}), 6.04(1 \mathrm{H}, \mathrm{d}, \mathrm{J} 2.2$ $\mathrm{Hz}, \mathrm{CHCHO}), 1.79\left(3 \mathrm{H}, \mathrm{s}, \mathrm{CH}_{3}\right), 0.95$ (9H, s, t-butyl), $0.23(6 \mathrm{H}, \mathrm{s}$, dimethyl); $\delta c\left(62.5 \mathrm{MHz}, \mathrm{CDCl}_{3}\right) 153.2,131.5,113.9,92.5,26.1$, 26.0, 18.5, 8.83, -2.55, -4.6; m/z (C.I) $213\left(\mathrm{MH}^{+}, 33 \%\right), 212$ (100\%), 181 (17\%), 169 (4.9\%), 130 (8.8\%), $\mathrm{C}_{11} \mathrm{H}_{21} \mathrm{SiO}_{2}$, requires 213.1312, found 213.1316

\section{5-(But-3-enyl)-3-methylfuran-2(5H)-one (3)}

The title compound was isolated as a pale yellow oil (22 $\mathrm{mg}, 9 \%)$ $V_{\max }$ (thin film) 3019, 2924, 1751, 1646, 1446, 1423, 928; $\delta_{H}(250$ $\left.\mathrm{MHz}, \mathrm{CDCl}_{3}\right) 6.96(1 \mathrm{H}, \mathrm{m}, \mathrm{CH}=\mathrm{C}), 5.70\left(1 \mathrm{H}, \mathrm{dt}, J_{\text {trans }} 17.1, \mathrm{~J}_{\text {cis }}\right.$ 10.3, J 6.8, $\left.\mathrm{CH}=\mathrm{CH}_{2}\right), 4.99-4.89\left(2 \mathrm{H}, \mathrm{m}, \mathrm{CH}_{2}=\mathrm{CH}\right), 4.83-4.80(1 \mathrm{H}$ $\mathrm{m}, \mathrm{CHO}), 2.15\left(2 \mathrm{H}, \mathrm{bq}, \mathrm{J} 7.9 \mathrm{~Hz}, \mathrm{CH}_{2} \mathrm{CH}_{2} \mathrm{CHO}\right), 1.81(3 \mathrm{H} \mathrm{s}$, $\left.\mathrm{CH}_{3} \mathrm{C}=\mathrm{C}\right)$, 1.73-1.61 $(2 \mathrm{H}, \mathrm{m} \mathrm{CH} 2 \mathrm{CHO}) ; \quad \delta_{\mathrm{c}}\left(62.5 \mathrm{MHz}, \mathrm{CDCl}_{3}\right)$ 174.6, 149.0, 137.1, 130.3, 116.3, 80.8, 33.1, 31.8, 30.1; m/z (C.I) $152\left(\mathrm{MH}^{+}, 1.3 \%\right), 130(100 \%), 118(70 \%), \quad \mathrm{C}_{9} \mathrm{H}_{13} \mathrm{O}_{2}$, requires 153.0909, found 153.0924

4-methyl-3methylene-hexahydrocyclopenta[b]furan-2-one (4) The title compound (4) was isolated as a colourless oil $(156 \mathrm{mg}$, $78 \%$ ); (thin film $\left./ \mathrm{cm}^{-1}\right), 2933,1751,1644,1442,1430,922 ; \delta_{H}(400$ $\left.\mathrm{MHz}, \mathrm{CDCl}_{3}\right) 6.18\left(1 \mathrm{H}, \mathrm{bs}, \mathrm{CH}_{2}=\mathrm{CH}\right), 5.62\left(1 \mathrm{H}, \mathrm{bs}, \mathrm{CH}_{2} \mathrm{CH}\right), 4.16$ $(1 \mathrm{H}, \mathrm{q}, \mathrm{J} 5.4 \mathrm{~Hz}, \mathrm{~J} 2.2 \mathrm{~Hz}, \mathrm{CHO}), 2.76(1 \mathrm{H}, \mathrm{dd}, J 5.6 \mathrm{~Hz}, \mathrm{~J} 1.9 \mathrm{~Hz}$, $\mathrm{CHCHO}), 1.91-1.60\left(3 \mathrm{H}, \mathrm{m}, \mathrm{CH}_{2} \mathrm{CHO}, \mathrm{CHCH}_{3}\right), 1.59-1.53(1 \mathrm{H}, \mathrm{m}$, $\left.\mathrm{CH}_{2} \mathrm{CHCH}_{3}\right), 1.35-1.1 .30\left(1 \mathrm{H}, \mathrm{m}, \mathrm{CH}_{2} \mathrm{CHCH}_{3}\right), 1.08(3 \mathrm{H}, \mathrm{d}, \mathrm{J} 6.6 \mathrm{~Hz}$, $\left.\mathrm{CH}_{3}\right) ; \delta_{\mathrm{c}}\left(100 \mathrm{MHz}, \mathrm{CDCl}_{3}\right)$ 174.3, 133.1, 120.3, 88.4, 53.4, 41.5, $31.5,29.4,17.7 ; \mathrm{m} / \mathrm{z}$ (C.I) $153\left(\mathrm{MH}^{+}, 100 \%\right), \mathrm{C}_{9} \mathrm{H}_{12} \mathrm{O}_{2}$, requires 153.0916, found 153.0914;

The synthesis on a suitable scale of the key bicyclic lactone (4) would require an efficient and robust synthesis of the precursor (3). Initial inspection of the intermediate (3) suggests that it could be conveniently assembled by coupling the C-5 cabanion of 3-methyl$2(5 \mathrm{H})$-furanone $(1)$ with the terminal cation of 4 -bromobutene in a 1,4 addition protocol. Once this is achieved, subsequent modification is required, which involves the cleavage of the 1,3dioxalane to aldehyde and a further ene-reaction protocol would afford bicyclic lactone (4). Unfortunately, the behaviour of 2furanolate ions is inconsistent. Nicholas \& Pattenden (1982) observed that the lithium enolate obtained from 3-methyl-2(5H)furanone (1) on alkylation with various ally bromides gives both $\mathrm{C}-3$ and $\mathrm{C}-5$ substitutions. It was envisaged that $\mathrm{C}-5$ regioselectivity could be induced by recourse to the 2-(trialkylsiloxy) furan, which behaves as the equivalent of the localized $\mathrm{C}-5$ of the $2(5 \mathrm{H})$ furanone entity (1). Protection of the carbonyl group of 3-methyl-2(5H)-furanone (1) was achieved following the procedure reported by Jefford et al., (1992). It was envisaged that compound (2) could conveniently furnish compound (3) with high regioselectivity. The possibility that (1) could be converted to (3) was considered on the basis of a report by Jefford et al., (1992) that $\omega$-bromogeranyl acetate could undergo alkylation at C-5 position of siloxyfurans to furnish the corresponding butenolides in good yields. This model compound was considered to explore the efficacy of this transformation. It was envisaged that activation with silver salt could provide the desired selectivity. Having the essential reagents in hand, the next step was set out to put them together to create the precursor (3). The coupling was achieved with a stiochiometric amount of silver trifluoroacetate and, in keeping with previous findings of Jefford et al., (1992) alkylation occurred with high regioselectivity. Unfortunately in our systems the yield was found to be $9 \%$, when 4-bromobutene was used as the coupling agent. In an attempt to establish optimized conditions for this reaction, it was discovered the yield could be greatly increased to $69 \%$ for (3), when the temperature was kept at $-78^{\circ} \mathrm{C}$ during the addition of 4 iodobutene (5) (Scheme 3).

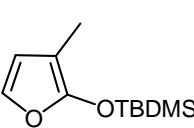

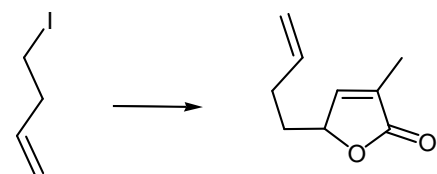

(5)

(3)

\section{Scheme 3. REGIOSELECTIVE ALKYLTION}

\section{Lewis Acid catalised Carbonyl Ene-reaction}

The attempted synthesis of the cis-fused bicyclic lactone(4) was to involve the reactions of (3) using an ene-reaction using procedure reported by Snider et al., (1982). According to this method, $\mathrm{Me}_{2} \mathrm{AICl}$ was added to solutions of (3) in DCM at $-78{ }^{\circ} \mathrm{C}$ under nitrogen and the resulting mixtures were allowed to warm to room temperature with stirring for 48 hours. After workup, ${ }^{1} \mathrm{H}$ NMR analysis revealed that (4) was formed. The protocol was repeated with different Lewis acids to isolate the endo-diastreoisomer (4) in good yield. The stereochemical assignment of -cis at ring junction and the endo methyl group were achieved via nOe.

\section{TABLE 1. LEWIS ACID CATALYZED ENE REACTION OF PRECURSOR (3)}

\begin{tabular}{lllc}
\hline Entr) & Reagents & Solvent & Yields (4) \\
\hline 1 & $\mathrm{BF}_{3} . \mathrm{OEt}_{2}$ & DCM & 78 \\
2 & $\mathrm{BF}_{3} \mathrm{OEt}_{2}$ & THF & 72 \\
3 & $\mathrm{AlCl}_{3}$ & DCM & 74 \\
3 & $\mathrm{MgBr}_{\text {OOEt }}$ & THF & 82 \\
4 & $\mathrm{Me}_{2} \mathrm{AlCl}$ & DCM & 61 \\
\hline
\end{tabular}

$\mathrm{BF}_{3} . \mathrm{OEt}_{2}, \mathrm{AlCl}_{3}, \mathrm{MgBr}$.OEt2 and $\mathrm{Me}_{2} \mathrm{AlCl}$ catalyzed the intramolecular ene reactions. The best condition for the expeditious preparation of 8-memebered bicyclic lactone (4) turned out to be by the use of $\mathrm{MgBr}$.OEt 21.3 equivalent at $-78{ }^{\circ} \mathrm{C}$ for 3 hours. The yields obtained in these cyclizations were invariably good and selectivity was high.

\section{REFERENCES}

Amarego, W. L. F., \& Perrin, D. D. (1998). Purification of Laboratory Chemicals, Pergamon Press Oxford

Boukouvalas, J., Jefford, C. W., \& Sledeski, A.. W. (1992). The alkylation of silyl enol ethers with $S_{N} 1$-unreactive iodides in the presence of silver trifluoroacetate. Tetrahedron Letters. 33:1855.

Karras, M., Price, R. T., Rodni, D. J., \& Snider, B. B. (1982). Alkylaluminum halide induced cyclization of unsaturated carbonyl compounds. Journal of Organic Chemistry. 47:4538.

Nicholas, G., \& Pattenden, G. (1982). Naturally occurring 5methyoxy-3(2H)-furanones. Re-assignment of structures to the aspertetronin group of natural products. Tetrahedron Letters. 23:589.

Snider, B. B. (1991). Comprehensive Organic Synthesis, BM Trost, Ed., Pergamon Press Oxford. 2:527 